\title{
Inhibin Reduces Spermatogonial Numbers in Testes of Adult Mice and Chinese Hamsters
}

\author{
FEDERICA M. F. VAN DISSEL-EMILIANI, ARIJAN J. GROOTENHUIS, \\ FRANK H. DE JONG, AND DIRK G. DE ROOIJ \\ Department of Cell Biology, Medical Faculty, University of Utrecht (F.M.F.v.D.-E., D.G.d.R.), 3508 TD \\ Utrecht; and the Department of Biochemistry, Division of Chemical Endocrinology, Erasmus University \\ Rotterdam (A.J.G., F.H.d.J.), 3000 DR Rotterdam, The Netherlands
}

\begin{abstract}
Bovine follicular fluid (bFF) injected ip in mice during 2 days $(65,000 \mathrm{U}$ inhibin/day, $1 \mathrm{U}$ inhibin the activity in $1 \mu \mathrm{g}$ bFF protein) caused a significant decrease in the numbers of $A_{4}$, intermediate (In), and $B$ spermatogonia to $91 \%,-74 \%$, and $67 \%$ of the control values, respectively. The numbers of undifferentiated spermatogonia remained unchanged. These injections suppressed peripheral FSH levels to $6 \%$ of the control values, suggesting that FSH might be the modulator of the effects on spermatogenesis.

However, in the Chinese hamster, intratesticular injections of bFF during 4 days (6500 $\mathrm{U}$ inhibin/day into one testis) also caused a significant decrease in the numbers of $A_{3}$, In, $B_{1}$, and $\mathrm{B}_{2}$ spermatogonia to $86 \%, 61 \%, 55 \%$, and $94 \%$ of the control values, respectively. Similarly, treatment with a partially purified inhibin preparation from rat Sertoli cell-conditioned medium (rSCCM) during 4 days (Mono $Q$ fraction; $1512 \mathrm{U}$ inhibin/ day; $37.8 \mu \mathrm{g}$ protein) caused a significant decrease in the numbers of $A_{3}, I n, B_{1}$, and $B_{2}$ spermatogonia to $90 \%, 87 \%, 66 \%$, and $93 \%$ of the control values, respectively. Treatment with a highly
\end{abstract}

purified inhibin preparation from rSCCM during 4 days $(30 \mathrm{~K}$ inhibin; $750 \mathrm{U}$ inhibin/day; $100 \mathrm{ng}$ protein) significantly decreased the numbers of In and $B_{1}$ spermatogonia to, respectively, $87 \%$ and $91 \%$ of the control values. These effects were limited to the testis into which the material was injected; the contralateral testis or testes injected with control fluid always showed normal numbers of spermatogonia. This implies that the effects on the seminiferous epithelium are not FSH mediated.

Intratesticular injections of bFF or pure inhibin did not affect the number of undifferentiated spermatogonia. However, the Mono $Q$ fraction caused a significant increase in the numbers of undifferentiated spermatogonia in stages IV-VII of the cycle, suggesting the presence of a mitogenic factor for undifferentiated spermatogonia in rSCCM which is not present or is counteracted in $\mathrm{bFF}$.

The results suggest that inhibin may have a role in the regulation of spermatogonial development in the adult animal. (Endocrinology 125: 1899-1903, 1989)
$\mathrm{I}_{\mathrm{s}}^{\mathrm{N}}$ NHIBIN is a glycoprotein hormone "which inhibits gonadotropin production and/or secretion, preferentially that of FSH" $(1,2)$. While it has been demonstrated that inhibin plays a key role in the regulation of peripheral FSH levels during the early stages of spermatogenesis in the rat (3-8), the physiological role of inhibin as a feedback regulator of FSH secretion in the adult animal remains to be determined $(9,10)$. Large amounts of inhibin have been found in testicular homogenates of adult rats $(4,6)$. Hence, it is possible that inhibin fulfills a function in the adult testis not involving its feedback action on FSH secretion. In fact, several pieces of evidence have suggested paracrine roles for inhibin and/or inhibin-related peptides. Both the Leydig cells (11) and spermatogonia (8) have been suggested as intratesticular targets for inhibin.

To gain more insight into the role of inhibin on adult

Received March 23, 1989.

Address requests for reprints to: Dr. Federica M. F. van DisselEmiliani, Department of Cell Biology, Medical Faculty, University of Utrecht, P.O. Box 80.157, 3508 TD Utrecht, The Netherlands. spermatogenesis, we examined the effects of administration of bovine follicular fluid (bFF) and partially and highly purified inhibin preparations from rat Sertoli cellconditioned medium (rSCCM) on spermatogonial development in adult mice and Chinese hamsters.

\section{Materials and Methods}

\section{Animals}

Male Chinese hamsters (12 weeks old) and Cpb-N mice were obtained from the Animal Breeding Station HSD/CPB (Zeist, The Netherlands). Mice were mated at random in our laboratory, and their offspring (12 weeks old) were used in this investigation. All animals were kept under controlled conditions of light (lights on, 0445-1900 h) and temperature (22-24 C).

\section{Experimental protocols}

$\operatorname{Exp} I$. The aim of this experiment was to investigate whether systemic injections of bFF could affect spermatogenesis of adult mice. 
Charcoal-treated bFF (1 U inhibin/ $\mu$ g protein; $65 \mu \mathrm{g}$ protein/ $\mu \mathrm{l})$ was prepared as previously described (12). Saline $(0.9 \%$ $\mathrm{NaCl}$ ) was used as control material. The plasma of an ovariectomized cow (bPcas) was used as an additional control material, since its protein concentration is similar to that of follicular fluid (13), and no inhibin activity is present.

Mice were injected ip with $\mathrm{bFF}$, saline, or bPcas. Groups of three mice were injected twice daily with $\mathrm{bFF}(0.5 \mathrm{ml}$ each time), during $1(24 \mathrm{~h} \mathrm{bFF})$ or 2 days $(48 \mathrm{~h} \mathrm{bFF})$. One group of three mice was injected twice on the first day and once on the second day $(0.5 \mathrm{ml}$ each time; $32 \mathrm{~h} \mathrm{bFF})$. Groups of four mice were injected with control material twice daily $(0.5 \mathrm{ml}$ each time) during 2 days. Eight hours ( $32 \mathrm{~h} \mathrm{bFF})$ or $16 \mathrm{~h}(24 \mathrm{~h} \mathrm{bFF}$, $48 \mathrm{~h} \mathrm{bFF}$, and control groups) after the last injection of bFF or control material, animals were killed for testicular histology.

Exp II. The aim of this experiment was to investigate whether the effects caused by bFF were mediated by suppressed FSH levels or whether bFF could affect spermatogenesis directly. Therefore, the material was injected intratesticularly. As mice could not be used for this purpose due to their small testis size [testis weight, $86 \pm 2 \mathrm{mg} /$ testis (mean $\pm \mathrm{SEM}$ ) $\mathrm{n}=8$ ], adult Chinese hamsters were used instead (testis weight, $1.00 \pm 0.05$ $\mathrm{g} /$ testis; $\mathrm{n}=8$ ). The same $\mathrm{bFF}$ preparations and control materials were used as those used for the mice.

Under light ether anesthesia the hamsters received intratesticular injections of bFF, saline, or bPcas. Groups of three hamsters were injected once daily with bFF $(0.1 \mathrm{ml}$ each time $)$ during 2 ( $48 \mathrm{~h} \mathrm{bFF}$ ), 3 ( $72 \mathrm{~h} \mathrm{bFF}$ ), or 4 days ( $96 \mathrm{~h} \mathrm{bFF}$ ). Groups of four hamsters were injected with control material once daily during 4 days $(0.1 \mathrm{ml}$ each time). Twenty-four hours after the last injection of bFF or control material, animals were killed for testicular histology. The contralateral testes of animals injected with $\mathrm{bFF}$ during 4 days were used to evaluate whether the effects caused by bFF were local or mediated by FSH.

Exp III. To find out whether the effects were indeed caused by inhibin and not by other factors also present in bFF (14-18), a partially purified inhibin preparation from ISCCM (Mono $Q$ fraction) was used in this experiment. The effects on spermatogenesis in adult Chinese hamsters were investigated.

The partially purified inhibin preparation ( $40 \mathrm{U}$ inhibin $/ \mu \mathrm{g}$ protein; $378 \mathrm{ng}$ protein $/ \mu \mathrm{l}$ ) was isolated from $\mathrm{rSCCM}$ as described previously (19). Tris buffer (Tris- $\mathrm{HCl}, \mathrm{pH}$ 7.9) was used as control material.

Groups of four Chinese hamsters received intratesticular injections, under light ether anesthesia, of the Mono $Q$ fraction or control material once a day during four days $(0.1 \mathrm{ml}$ each time). Twenty-four hours after the last injection of the partially purified inhibin preparation or control material, animals were killed for testicular histology. The contralateral testes of those injected with the Mono $Q$ fraction were used as the controls for the local effect of the material.

Exp IV. Finally, in this experiment the effects of a highly purified inhibin preparation (30K inhibin) on spermatogenesis of adult Chinese hamsters were evaluated.

The highly purified inhibin preparation (7500 U inhibin $/ \mu \mathrm{g}$ protein; $4 \mathrm{ng}$ protein/ $\mu \mathrm{l}$ ) was isolated from $\mathrm{rSCCM}$ as previously described (19). The vehicle (0.04\% BSA in saline) was used as control material.

Groups of five Chinese hamsters received intratesticular injections, under a light ether anesthesia, of $30 \mathrm{~K}$ inhibin $(25 \mu \mathrm{l}$ each time) once a day during 4 days. As testes contralateral to those injected with $b F F$ or the Mono $Q$ fraction were not affected by these treatments (see Results), contralateral testes were used here for control injections. These were given at the same time as the injections of $30 \mathrm{~K}$ inhibin ( $25 \mu \mathrm{l}$ each time). Twenty-four hours after the last injection of inhibin or control material, animals were killed for testicular histology.

\section{Histological studies}

Seminiferous tubules were prepared according to the method of Clermont and Bustos-Obregon (20), fixed in Bouin's fluid, stained with Harris' hematoxylin, and mounted in toto. Spermatogonial cell types and epithelial stages in the mouse and the Chinese hamster were classified according to the methods of Oakberg (21), de Rooij (22), and Oud and de Rooij (23). Differentiating $\left[A_{1}, A_{2}, A_{3}, A_{4}\right.$, intermediate (In), and $B$ spermatogonia in the mouse, and $A_{1}, A_{2}, A_{3}$, In, $B_{1}$, and $B_{2}$ spermatogonia in the Chinese hamster] and undifferentiated spermatogonia and Sertoli cells were counted in the various stages of the seminiferous epithelium. Counts were made using an ocular grid (area of $144 \mu \mathrm{m}^{2}$ ) with a $\times 100$ oil immersion objective placed over the domed center of the tubule. All spermatogonia having at least half of their nucleus within the frame were counted. The numbers found were related to the number of Sertoli cells present in the same areas. For each cell type a total area containing 1000 Sertoli cells, corresponding to about $7000 \mu \mathrm{m}^{2}$, was studied (for each animal, 50-100 segments of seminiferous tubules, $0.5-1.0 \mathrm{~cm}$ long, were used).

\section{Hormone estimations}

In vitro inhibin bioassay. For the determination of the endogenous inhibin concentration of Chinese hamster testes, homogenates were prepared from testes of four untreated adult Chinese hamsters, as described previously (4), and the cytosols were tested in the inhibin bioassay. Inhibin bioactivity was determined by in vitro suppression of basal FSH release from dispersed rat pituitary cells (24). Charcoal-treated bFF was used as a standard of inhibin activity.

RIA of FSH. Peripheral FSH concentrations in the mouse were estimated by RIA, (24) using NIDDK rat FSH RP-1 as a standard. Blood samples were collected in heparinized tubes, $16 \mathrm{~h}$ after the last injection of bFF or saline. Plasma (three and four samples for the bFF- and saline-treated groups, respectively) was stored at $-20 \mathrm{C}$ until further processing for the RIA.

\section{Statistical analysis}

The significance of differences between mean values of different treatment groups in Exp I, II, and III was estimated using Student's $t$ test (under assumption of normality). The matched pair Student's $t$ test was used in Exp IV. Differences were considered significant when $P<0.05$. 


\section{Results}

Effect of systemic injection of bFF on spermatogonial numbers in the adult mouse

Although Student's $t$ test may not be completely reliable with the small numbers of mice used in this pilot experiment, the results strongly suggest an effect of bFF on the numbers of differentiating spermatogonia.

The first effect became clear after $24 \mathrm{~h}$ of treatment. By that time the numbers of In and B spermatogonia were lowered to $89 \%$ and $91 \%$, respectively, of the control values (saline-injected group; Fig. 1). When the treatment was given for 2 days, the effect became more pronounced; the numbers of In and B spermatogonia were $74 \%$ and $67 \%$ of the control values, respectively (Fig. 1). Furthermore, degeneration of these cells could clearly be seen (Fig. 2). A slight decrease in the numbers of $A_{4}$ spermatogonia to about $91 \%$ of the control values was also detected. The numbers of $A_{1}, A_{2}$, and $A_{3}$ spermatogonia were not affected by treatment at all times studied (results not shown).

Injections of bFF never affected the number of undifferentiated spermatogonia scored in the same epithelial stages as the differentiating spermatogonia (results not shown).

Treatment with bPcas did not have any effect on spermatogonial numbers compared to that in the salineinjected group (Fig. 1).

The peripheral FSH levels in mice treated with $\mathrm{bFF}$ during 2 days were significantly lowered to $6 \%$ of the control values $[162 \pm 21 \mathrm{ng} \mathrm{FSH} / \mathrm{ml}(\mathrm{n}=3)$ vs. $4521 \pm$

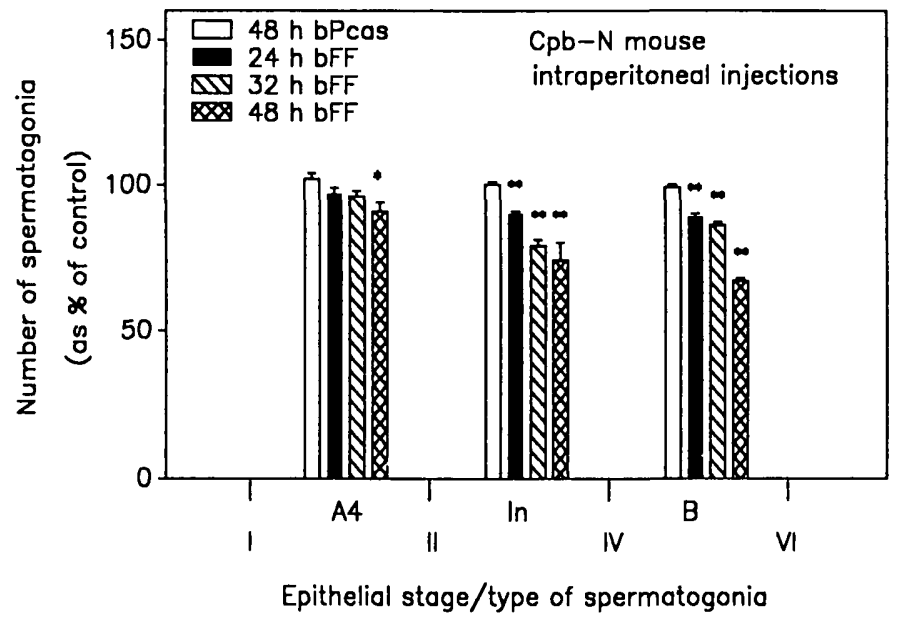

FIG. 1. Effect of systemic injection of bFF or bPcas on the numbers of differentiating spermatogonia in the adult mouse. Results have been expressed relative to those determined in saline-injected animals (mean \pm SEM; $\mathrm{n}=3$ or 4 ). ${ }^{*}, P<0.05$; $^{* *}, P<0.01$ (by $t$ test). The mean number of spermatogonia in each treatment group was calculated from the numbers of the different types of spermatogonia per 1000 Sertoli cells found per animal (an area containing 1000 Sertoli cells corresponds to about $7000 \mu \mathrm{m}^{2}$ ). For each animal, 50-100 segments of seminiferous tubules $(0.5-1.0 \mathrm{~cm}$ long) were used.
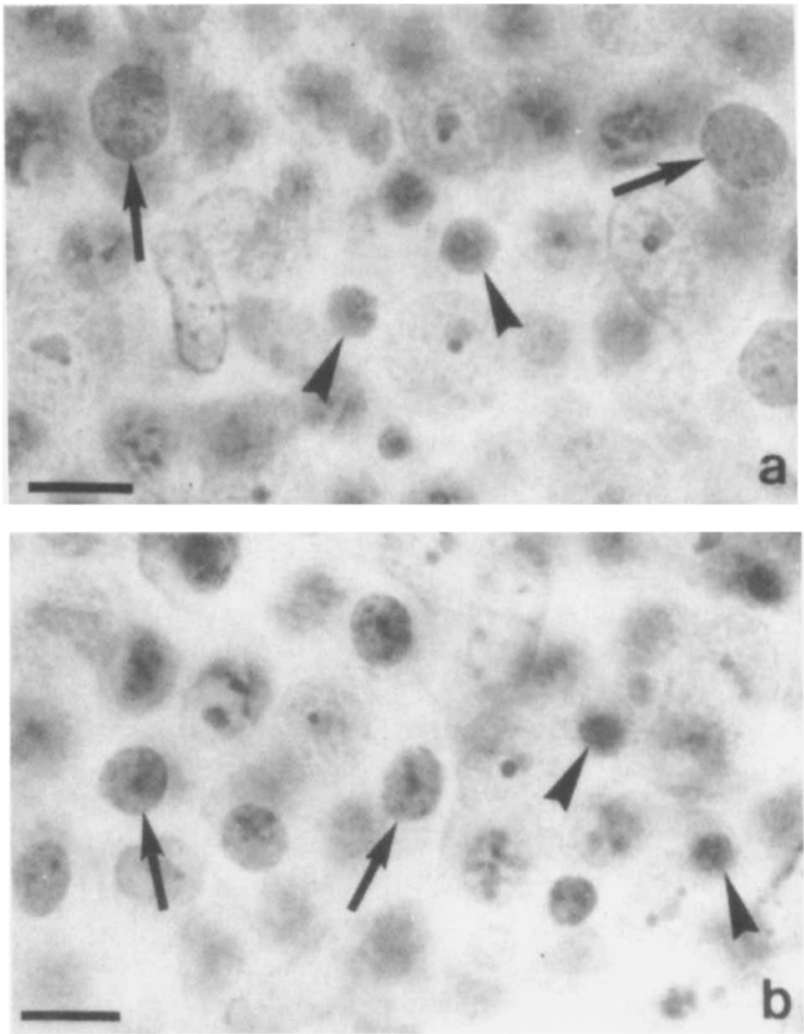

FIG. 2. Micrograph of mouse seminiferous tubules mounted in toto, showing degenerations of the In (a) and B spermatogonia (b) after bFF treatment during 2 days. The degenerating spermatogonia (arrowheads) were found adjacent to normal spermatogonia (arrows). Magnification, $\times 1068$; bar $=9 \mu \mathrm{m}$.

$1298 \mathrm{ng} \mathrm{FSH} / \mathrm{ml}$ in the control group $(\mathrm{n}=4)$; mean \pm SEM); $P<0.01$ ].

\section{Effect of intratesticular injection of bFF on spermatogonial numbers in the adult Chinese hamster}

The effects of intratesticular injections of bFF were comparable to those observed after systemic injection of the material in the mouse. In the treated testis, the numbers of differentiating spermatogonia were clearly affected after $72 \mathrm{~h}$ of treatment (Fig. 3). At this time, the numbers of In and $B_{1}$ spermatogonia were lowered to $96 \%$ and $89 \%$ of the control values, respectively (salineinjected group). The degenerative process became more clear with increasing duration of the treatment, and by 4 days even the numbers of $\mathrm{B}_{2}$ spermatogonia, which originally were not influenced by the treatment ( $99 \%$ of the control values after $72 \mathrm{~h}$ of treatment), were also lowered to $94 \%$ of the control values. At this time the numbers of $I n$ and $B_{1}$ spermatogonia were decreased to $61 \%$ and $55 \%$, respectively, of the control values. The treatment also affected the numbers of $\mathrm{A}_{3}$ spermatogonia, which by 4 days were decreased to $86 \%$ of the control values. No effect was found on $A_{1}$ and $A_{2}$ sper- 


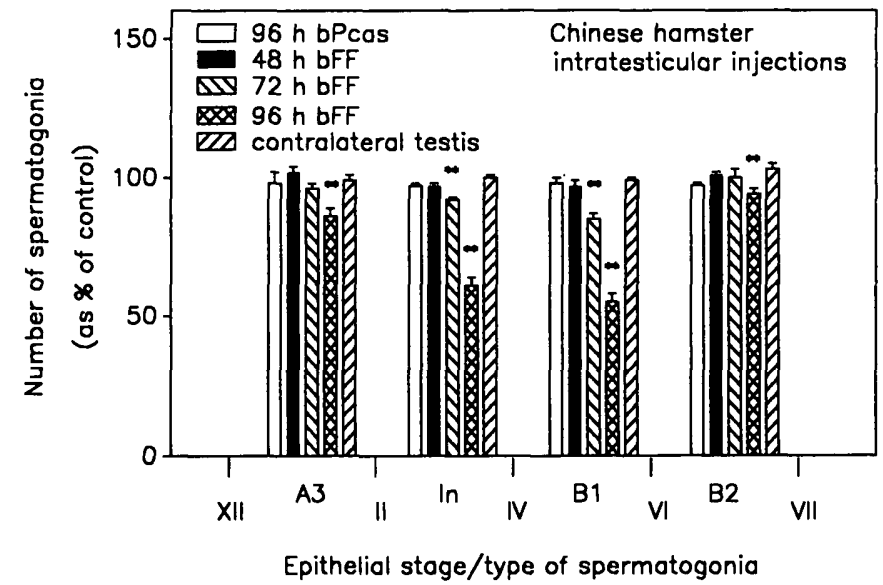

Fig. 3. Effect of intratesticular injection of bFF or bPcas on the numbers of differentiating spermatogonia in the adult Chinese hamster. Results have been expressed relative to those obtained in saline-injected animals (mean \pm SEM; $\mathrm{n}=3$ or 4 ). ${ }^{* *}, P<0.01$ (by $t$ test). The mean number of differentiating spermatogonia in each treatment group was calculated as described in Fig. 1.

matogonia (results not shown). The numbers of undifferentiated spermatogonia scored in the same stages as the differentiating spermatogonia were not affected by the treatment at any time studied (results not shown). All counts made in testes contralateral to those injected with $\mathrm{bFF}$ for 4 days were not significantly different from counts made in animals injected with saline (Fig. 3).

The inhibin activity measured in testicular homogenates of normal adult Chinese hamsters was $800 \pm 50 \mathrm{U}$ inhibin/testis $[950 \pm 37 \mathrm{U}$ inhibin/g testicular tissue (mean $\pm \mathrm{SEM}) ; \mathrm{n}=4$ ].

Effect of intratesticular injection of the Mono $Q$ fraction from rSCCM on spermatogonial numbers in adult Chinese hamsters

When the inhibin-containing Mono $Q$ fraction was used, comparable effects were obtained as after the $\mathrm{bFF}$ treatment. A significant lowering of the numbers of $\mathrm{A}_{3}$, In, $B_{1}$, and $B_{2}$ spermatogonia to, respectively, $90 \%, 87 \%$, $66 \%$, and $93 \%$ of the control values was found (Fig. $4 \mathrm{a}$ ). In contrast to what was found with bFF the number of undifferentiated spermatogonia was also affected by this treatment. Their numbers were significantly increased in stages IV-VI and VI-VII of the epithelial cycle to $176 \%$ and $145 \%$, respectively, of the control values (Fig. 4b). Counts in testes contralateral to those injected with the Mono $\mathrm{Q}$ fraction were not different from those in the control testes (Fig. 4a).

Effect of intratesticular injection of $30 \mathrm{~K}$ inhibin from rSCCM on spermatogonial numbers in adult Chinese hamsters

As with the Mono $Q$ fraction, the numbers of In and $B_{1}$ spermatogonia were significantly lowered in the in-

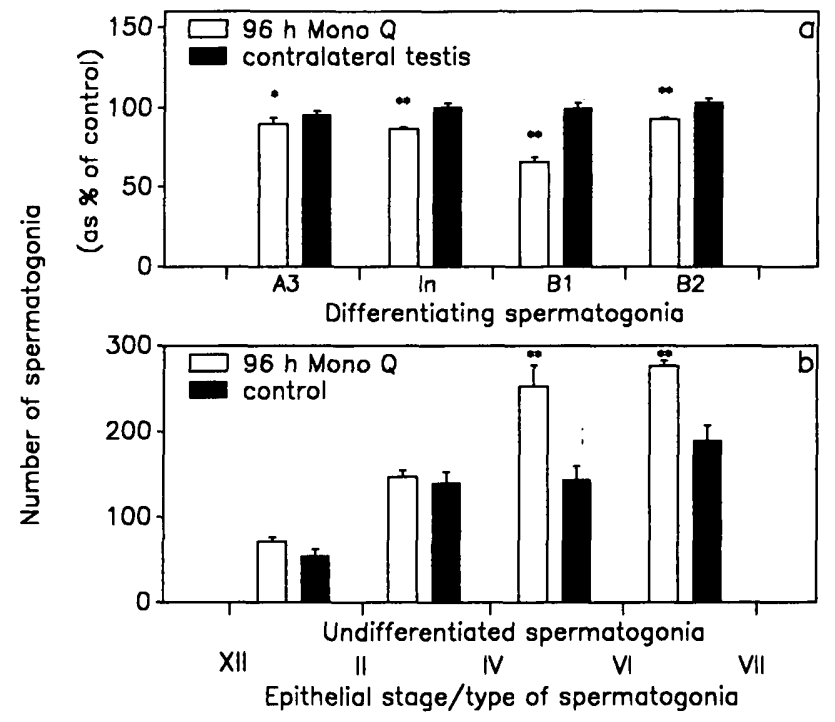

FiG. 4. Effect of intratesticular injection of a partially purified rat inhibin preparation (Mono $Q$ fraction) on the numbers of differentiating (a) and undifferentiated (b) spermatogonia in the adult Chinese hamster. The numbers of differentiating spermatogonia have been expressed relative to those obtained in Tris buffer-injected controls (mean $\pm \mathrm{SEM} ; \mathrm{n}=4)$. ${ }^{*}, P<0.05$; $^{* *}, P<0.01$ (by $t$ test). The numbers of undifferentiated spermatogonia are expressed as mean numbers of spermatogonia per 1000 Sertoli cells. The mean number of spermatogonia in each treatment group was calculated as described in Fig. 1.

TABLE 1. Effect of intratesticular injection of highly purified $30 \mathrm{~K}$ rat inhibin on the numbers of differentiating and undifferentiated spermatogonia in the adult Chinese hamster

\begin{tabular}{lcc}
\hline $\begin{array}{l}\text { Cell type } \\
\text { (stage of the cycle) }\end{array}$ & $\begin{array}{c}\text { Contralateral } \\
\text { testis }\end{array}$ & 30K Inhibin \\
\hline $\begin{array}{c}\text { Differentiating } \\
\text { spermatogonia }\end{array}$ & & \\
A $_{3}$ (XII-II) & $266 \pm 3$ & $263 \pm 4$ \\
In (II-IV) & $514 \pm 6$ & $446 \pm 6^{*}$ \\
B $_{1}$ (IV-VI) & $1049 \pm 9$ & $959 \pm 2^{*}$ \\
B $_{2}$ (VI-VII) & $2084 \pm 40$ & $2076 \pm 13$ \\
Undifferentiated & & \\
$\quad$ spermatogonia & & \\
XII-II & $58 \pm 6$ & $54 \pm 6$ \\
II-IV & $136 \pm 6$ & $124 \pm 22$ \\
IV-VI & $168 \pm 15$ & $165 \pm 23$ \\
VI-VII & $203 \pm 24$ & $211 \pm 21$ \\
\hline
\end{tabular}

The mean number of spermatogonia in each treatment group was calculated as described in Fig. 1. Values are the mean $\pm \operatorname{SEM}(n=5)$.

${ }^{*} P<0.01$ (by matched pair $t$ test).

hibin-treated testis (Table 1). However, the numbers of $A_{3}$ and $B_{2}$ spermatogonia were unchanged compared to the control values. Also, the numbers of undifferentiated spermatogonia were not affected by the treatment (Table 1).

\section{Discussion}

The present results demonstrate that in the adult testis, increased levels of inhibin cause a decrease in the 
numbers of differentiating spermatogonia at particular stages of the epithelial cycle. As the systemic injections of bFF in mice also caused a significant decrease in peripheral FSH levels, the most likely explanation seemed to be that these effects were mediated by the suppression of FSH. However, comparable effects were obtained when bFF- or inhibin-containing preparations were administered intratesticularly. Furthermore, in Chinese hamsters, no effect on the numbers of differentiating spermatogonia were seen in the testes contralateral to those injected with bFF or the Mono $Q$ fraction. This indicates that inhibin has a local effect on spermatogonial development in the adult animal. Whether inhibin exerts its effects directly on the spermatogonia or through an action on Sertoli or interstitial cells is at this time unknown.

The effects of administration of inhibin are delayed in the Chinese hamster compared to those in the mouse (first effect seen after 72 vs. $24 \mathrm{~h}$ ). This may be due to the differences in the cell cycle duration of the differentiating spermatogonia in both animals $(57-60.5 \mathrm{~h}$ in the Chinese hamster vs. $27-30.5 \mathrm{~h}$ in the mouse) $(25,26)$.

The effects of inhibin seem to be dose dependent, as in the Chinese hamster intratesticular injections of 6500 $\mathrm{U}$ inhibin/day (bFF) caused a greater decrease in spermatogonial numbers than $1512 \mathrm{U}$ inhibin/day (Mono Q fraction) or $750 \mathrm{U}$ inhibin/day (30K inhibin). In the normal testis, the inhibin content was $800 \pm 50 \mathrm{U}$ inhibin. Hence, immediately after bFF injection, the inhibin content of the testis may have increased to about 8-fold the normal value, whereas with the Mono $Q$ fraction or the highly purified inhibin preparation the increase may only have been around 3- to 2-fold, respectively. However, it cannot be excluded that bFF affects spermatogenesis in a different way than the purified preparations from $\operatorname{rSCCM}(24,27)$.

Franchimont et al. (8) showed a decrease in testicular DNA synthesis in immature rats after treatment with a partially purified inhibin preparation from ram rete testis fluid. Their inhibin preparation was shown to affect DNA synthesis of In and B spermatogonia in vivo as well as in vitro. The researchers postulated that their inhibin preparation and the testicular chalone of Clermont and Mauger (28) were similar. However, the differences between the testicular chalone, which only acts on the proliferative activity of type A spermatogonia $(28,29)$, and the preparation of Franchimont et al. (8), which only influences the DNA synthesis of differentiating spermatogonia, suggest that other factors, possibly inhibin, were involved in the decrease in spermatogonial DNA synthesis. Although the researchers did not find any effect in adult rats, the local effect of inhibin on spermatogonial development described by Franchimont et al. (8) is reminiscent of our data. The effect on DNA syn- thesis may precede the degeneration of spermatogonia described in the present study. Alternatively, the decrease in testicular DNA synthesis may also be the result of degeneration of spermatogonia. The fact that Franchimont et al. (8) did not find an effect on adult spermatogenesis might be explained by the different sources of inhibin used and the different protocols applied.

The differentiating spermatogonia present in stages IVI of the epithelial cycle seem to be the most sensitive to increased levels of inhibin. The decrease in the numbers of $\mathrm{B}_{2}$ spermatogonia in the Chinese hamster is clearly due to the decrease in the numbers of their precursors, the $B_{1}$ spermatogonia, at an earlier time and do not reflect a sensitivity of these cells for inhibin.

It is not known as yet whether the production of inhibin varies with the stage of the epithelial cycle, as has been shown for various other Sertoli cell products (30). However, in the rat mRNA expression of the $\alpha$ and $\beta \mathrm{B}$-subunits of inhibin varied significantly during the cycle of the seminiferous epithelium (31). mRNA levels of both subunits were minimal in stages II-VI and VII-VIII. If the inhibin production is indeed low or absent in these stages, it is plausible that increased inhibin levels there could affect the seminiferous epithelium.

Spermatogonial degeneration of certain types of differentiating spermatogonia, such as $A_{1}, A_{2}$, and $A_{3}$ spermatogonia in the rat (32) or In spermatogonia in the ram and the bull (33), is a physiological phenomenon. The extent of these degenerations is strictly correlated to the density of the spermatogonia and enables the epithelium to regulate the density of the spermatocytes (34). In view of the present results, it is tempting to speculate that in a normally functioning adult testis, inhibin has a role in the regulation of spermatogonial numbers.

It is remarkable that the Mono $\mathbf{Q}$ fraction caused an increase in the numbers of undifferentiated spermatogonia in stages IV-VII after 4 days of treatment. Since the effects of injection with bFF or the Mono $Q$ fraction may be caused by different factors present in both preparations, it is likely that a factor in the Mono $Q$ fraction, which is not present in the highly purified inhibin preparation and is absent or counteracted in $\mathrm{bFF}$, enhances the proliferative activity of undifferentiated spermatogonia. Several growth factors have been described in the testis, such as the seminiferous growth factor (35) and Sertoli cell-secreted growth factor $(36,37)$. It is, however, not known whether these factors affect spermatogonial multiplication or differentiation. Studies are currently underway to isolate and characterize the mitogenic factor in the Mono $\mathrm{Q}$ fraction.

\section{Acknowledgments}

The authors wish to thank Mr. H. J. G. van de Kant, Mrs. H. 
Roepers, and Mrs. M. A. Timmerman for their skillful technical assistance. The authors also wish to thank the NIDDK (Bethesda, MD) for making available materials used in the RIA of FSH.

\section{References}

1. Burger HG, Igarashi M 1988 Inhibin: Definition and nomenclature, including related substances. Endocrinology 122:1701

2. de Jong FH 1988 Inhibin. Physiol Rev 68:555

3. Ultee van Gessel AM, Leemborg MG, de Jong FH, van der Molen HJ 1985 Influence of neonatal hemicastration on in-vitro secretion of inhibin, gonadotrophins and testicular steroids in male rats. $\mathrm{J}$ Endocrinol 106:259

4. Ultee van Gessel AM, de Jong FH 1987 Inhibin-like activity in Sertoli cell culture media and testicular homogenates from rats of various ages. J Endocrinol 113:103

5. Au CL, Robertson DM, de Kretser DM 1986 Measurement of inhibin and an index of inhibin production by rat testes during postnatal development. Biol Reprod 35:37

6. Rivier C, Cajander S, Vaughan J, Hsueh AJW, Vale W 1988 Age dependent changes in physiological action, content, and immunostaining of inhibin in male rats. Endocrinology 123:120

7. de Jong FH, Welschen R, Hermans WP, Smith SD, van der Molen HJ 1978 Effect of testicular and ovarian inhibin-like activity using in vitro and in vivo systems. J Androl [Suppl] 2:125

8. Franchimont P, Croze F, Demoulin A, Bologne R, Hustin J 1981 Effect of inhibin on rat desoxyribonucleic acid (DNA) synthesis in vivo and in vitro. Acta Endocrinol (Copenh) 98:312

9. Davies RV, Main SJ, Laurie MS, Setchell BP 1979 The effect of long-term administration of either a crude inhibin preparation or an antiserum to FSH on serum hormone levels, testicular function and fertility of adult male rats. J Reprod Fertil [Suppl] 26:183

10. Moudgal NR, Murthy HMS, Murthy GS, Rao AJ 1984 Regulation of FSH secretion in the primate by inhibin: studies in the Bonnet monkey ( $M$. radiata). In: Sairam MR, Atkinson LE (eds) Gonadal Proteins and Peptides and Their Biological Significance. World Scientific, Singapore, $p 21$

11. Hsueh AJW, Dahl KD, Vaughan J, Tucker E, Rivier J, Bardin CW, Vale W 1987 Heterodimers and homodimers of inhibin subunits have different paracrine action in the modulation of luteinizing hormone-stimulated androgen biosynthesis. Proc Natl Acad Sci USA 84:5082

12. van Dijk S, de Jong FH, van der Molen HJ 1984 Use of fast liquid chromatography in the purification of inhibin from bovine follicular fluid. Biochem Biophys Res Commun 125:307

13. Caravaglios R, Cilotti R 1957 A study of the proteins in the follicular fluid of the cow. J Endocrinol 15:273

14. Sluss PM, Reichert LE, Jr 1984 Porcine follicular fluid contains several low molecular weight inhibitors of follicle-stimulating hormone binding to receptor. Biol Reprod 30:1091

15. Tsutsumi I, Fugimori K, Nakamura RM, Mather JP, Ono T, diZerega GS 1987 Disruption of seminiferous epithelial function in the rat by ovarian protein. Biol Reprod 36:451

16. Vale W, Rivier J, Vaughan J, McClintock R, Corrigan A, Woo W, Karr D, Spiess J 1986 Purification and characterization of an FSHreleasing protein from procine ovarian follicular fluid. Nature 321:776

17. Ling N, Ying SY, Ueno N, Shimasaki S, Ech F, Hotta M, Guillemin R 1986 Pituitary FSH is released by a heterodimer of the $\beta$-subunits from the two forms of inhibin. Nature 321:779

18. Ying SY, Becker A, Ling N, Ueno N, Guillemin R 1986 Inhibin and beta type transforming growth factor (TGF- $\beta$ ) have opposite modulating effects on the follicle stimulating hormone (FSH)induced aromatase activity of cultured rat granulosa cells. Biochem Biophys Res Commun 136:969

19. de Jong FH, Grootenhuis AJ, Sander HJ, Steenbergen J, Timmerman MA, van Dijk S 1988 Comparison between inhibin from bovine follicular fluid and rat Sertoli cell culture medium. In: Burger HG, de Kretser DM, Findlay JK (eds) Inhibin-Non Steroidal Regulation of FSH Secretion. Raven Press, New York, vol 42:35

20. Clermont Y, Bustos-Obregon E 1968 Reexamination of spermatogonial renewal in the rat by means of seminiferous tubules mounted in toto. Am J Anat 122:237

21. Oakberg EF 1971 Spermatogonial stem-cell renewal in the mouse. Anat Rec 169:515

22. de Rooij DG 1973 Spermatogonial stem cell renewal in the mouse. I. Normal situation. Cell Tissue Kinet 6:281

23. Oud JL, de Rooij DG 1977 Spermatogenesis in the Chinese hamster. Anat Rec 187:113

24. Grootenhuis AJ, Steenbergen J, Timmerman MA, Dorsman ANRD, Schaaper WMM, Meloen RH, de Jong FH, Inhibin and activin-like activity in fluids from male and female gonads: different molecular weight forms and bioactivity/immunoreactivity ratios. J Endocrinol, 122:293

25. Monesi V 1962 Autoradiographic study of DNA synthesis and the cell cycle in spermatogonia and spermatocytes of mouse testes using tritiated thymidine. J Cell Biol 14:1

26. Lok D, de Rooij DG 1983 Spermatogonial multiplication in the Chinese hamster. I. Cell cycle properties and synchronization of differentiating spermatogonia. Cell Tissue Kinet 16:7

27. van Dijk S, Steenbergen J, Gielen JTh, de Jong FH 1985 Sexual dimorphism in immunoneutralization of rat and ovine inhibin. $J$ Endocrinol 11:255

28. Clermont Y, Mauger A 1974 Existence of a spermatogonial chalone in the rat testis. Cell Tissue Kinet 7:165

29. de Rooij DG 1980 Effects of testicular extracts on proliferation of spermatogonia in the mouse. Virchows Arch B Cell Pathol 33:67

30. Parvinen M 1982 Regulation of the seminiferous epithelium. Endocr Rev 3:404

31. Toppari J, Krummen LA, Kim WH, Swerdloff RS, diZerega GS, Ling N, Esch F, Shimasaki S, Bashin S, Expression of inhibin alpha and beta $B$ subunits is stage dependent during the cycle of the rat seminiferous epithelium. 10th Annual Testis Workshop, Baltimore MD, 1988, p 86 (Abstract)

32. Huckins C 1978 The morphology of spermatogonia degeneration in normal adult rats: an analysis using a simplified classification of the germinal epithelium. Anat Rec 190:905

33. Courot M, Hochereau-de Reviers MT, Ortavant R 1970 Spermatogenesis. In: Johnson AD, Gomes WR, Vandemark NL (eds) The Testis. Academic Press, New York, vol 1:339

34. de Rooij DG, Lok D 1987 Regulation of the density of spermatogonia in the seminiferous epithelium of the Chinese hamster. II. Differentiating spermatogonia. Anat Rec. 217:131

35. Bellve AR, Feig LA 1984 Cell proliferation in the mammalian testis: biology of the seminiferous growth factor. Recent Prog Horm Res 40:658

36. Holmes SD, Spotts G, Smith RG 1986 Rat Sertoli cells secrete a growth factor that blocks epidermal growth factor (EGF) binding to its receptor. J Biol Chem 261:4076

37. Buch JP, Lamb DJ, Lipschultz LI, Smith RG 1988 Partial characterization of a unique growth factor secreted by human Sertoli cells. Fertil Steril 49:658 